\title{
Radar geology: Techniques and results
}

\begin{abstract}
Radar images are a valuable source of information for the study of global geoscience processes. Synthetic Aperture Radar data have been used increasingly in support of geological mapping and in studies related to the investigations of structural geology and geologic hazards.
\end{abstract}

\section{Introduction}

The decade of the 1990s is the decade for radar remote sensing. The European Space Agency (ESA) has recently launched a European Remote Sensing satellite (ERS-1) that will provide multilook $\mathrm{C}$-band $(5.66-\mathrm{cm})$ images. Other planned programs will be the Japanese Earth Resources Satellite (JERS-1) L-band system and the Canadian Radarsat multilook, high-resolution C-band system. In addition, several airborne radar systems, commercial and experimental, are available in Canada and the United States.

In preparation for Radarsat, the Canada Centre for Remote Sensing (CCRS) has flown over 50 geological test sites between 1987 and 1992. CCRS's main objective is to determine what geological information can be extracted from Synthetic Aperture Radar (SAR) images or from its combination with other data sets. The radar data were flown in support of (1) geological mapping in glaciated and vegetated terrain, (2) structural geology investigations that are searching for mineral deposits and hydrocarbon traps, and (3) studies of geologic hazards including seismic hazards. The results of the airborne SAR campaign are encouraging for a number of multidisciplinary geological programs (summarized in table 1) and have led to the increased use of radar imagery in recent years. This article discusses the techniques and results of radar imagery in order to evaluate the contribution of SAR images to the study of global geoscience processes.

\section{Geological mapping}

Several studies have shown that SAR imagery is useful for geological mapping. For example, in glaciated and vegetated Quaternary terrains having flat areas and exposed soil, Singhroy and others (1992) have shown that the tonal differences on springtime radar imagery can help to detect the variability of soil moisture, which corresponds to the distribution of surficial materials. However, in rough or undulating terrain, the slope has a stronger influence on radar backscatter than the soil moisture has. Further research needs to be done in order to understand the relationship between radar backscatter and the porosity, texture, and moisture content of the underlying surficial materials. The potential of springtime radar imagery in revising and aiding ongoing, detailed Quaternary and engineering geology mapping will be realized in the near future. Several radar image-enhancement techniques have been used to delineate surficial materials. In relatively flat terrain without vegetation, a simple stretched image and a $5 \times 5$ directional filter provide an effective tool for discriminating materials. In areas that have a mix of exposed soil, vegetation, and moderately rolling relief, combinations of the Landsat Thematic Mapper (TM) bands, particularly TM bands 3 and 5 , and the stretched and filtered C-band radar image were useful. In areas where surficial materials are covered by natural vegetation (as in the case of most of northern Canada), the recommended technique for the delineation of surficial materials is to use a combination of the radar-landform and geobotanical relationships. More research needs to be conducted in order to understand fully these relationships and the influence of vegetation distribution on radar texture. However, where a close relationship exists between the distribution of surficial materials and the type and density of vegetation, a radar plus TM composite image provides a useful technique for Quaternary mapping.

Radar images also provide valuable information on landforms and terrain roughness. Because landforms provide clues to surficial materials, the radar images are, therefore, a useful and practical tool for Quaternary mapping. Kenny and others (1991) also have shown that enhanced springtime airborne SAR (C-HH and X-HH; HH, horizontally transmitted-horizontally received waves) combined with multispectral data are more suited to our interpreting landforms and surficial materials than are the existing 1:15,840-scale black and white aerial photographs. In other areas. Graham and Grant (1990) have interpreted $C$-band SAR prints having a $45^{\circ}$ incidence angle for reconnaissance surficial mapping. They easily identified major new lineaments, fold pattern, morainal topography, hummocky and ribbed moraines, grained tills, and surface erratics.

SAR, TM, and other geologic data have been integrated in multidisciplinary geological mapping programs. Mussakowski and others (1991) have produced customized sets of enhanced multiple data that consisted of the integration of SAR, magnetic data, and geology. Bowie and others (in press) have digitally integrated digital terrain models (DTM), lithology, and SAR data to produce a composite image map that facilitated interpretation of the Sudbury impact structure in central Ontario, Canada. They used an intensity, hue. saturation (IHS) transform in the integration process that produced the composite image map.

Lowman (1991), in evaluating the geological value of orbital radar and airborne C-band SAR in the Canadian Shield area, has focused on the Sudbury impact structure. He has noted that topography and the bedrock geology expressed by topography are well displayed on the airborne SAR and that little azimuth biasing is evident compared to that in orbital radar. This appears to be the result of a combination of the higher resolution in range and azimuth of the airborne SAR and C-band wavelength, as well as the $45^{\circ}$ incident angle, which is well suited for Canadian Shield terrain.

\section{Structural investigations}

$S_{\text {AR images have been used for structural geology investigations in }}$ support of mineral and hydrocarbon exploration. Image maps have been produced by the integration of SAR $(\mathrm{C}-\mathrm{HH})$, magnetic vertical gradient, and color and texture transforms (Rheault and others, 1991. and Harris, 1991). Figure 1 shows a C-band airborne SAR of the 

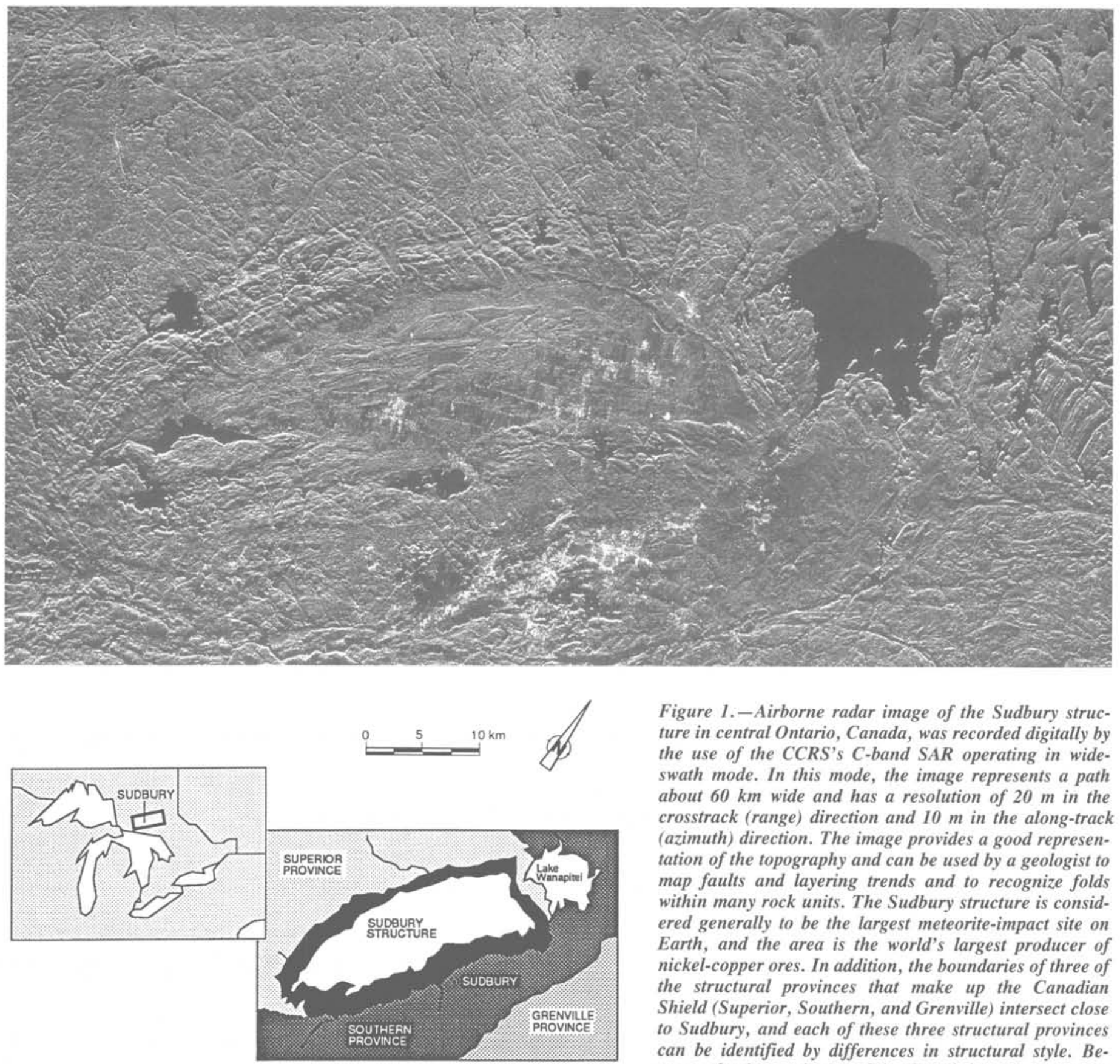

Figure 1.-Airborne radar image of the Sudbury structure in central Ontario, Canada, was recorded digitally by the use of the CCRS's C-band SAR operating in wideswath mode. In this mode, the image represents a path about $60 \mathrm{~km}$ wide and has a resolution of $20 \mathrm{~m}$ in the crosstrack (range) direction and $10 \mathrm{~m}$ in the along-track (azimuth) direction. The image provides a good representation of the topography and can be used by a geologist to map faults and layering trends and to recognize folds within many rock units. The Sudbury structure is considered generally to be the largest meteorite-impact site on Earth, and the area is the world's largest producer of nickel-copper ores. In addition, the boundaries of three of the structural provinces that make up the Canadian Shield (Superior, Southern, and Grenville) intersect close to Sudbury, and each of these three structural provinces can be identified by differences in structural style. Because the image is stored in digital format, it can be manipulated on an image analysis system. Provided by Canada Centre for Remote Sensing.

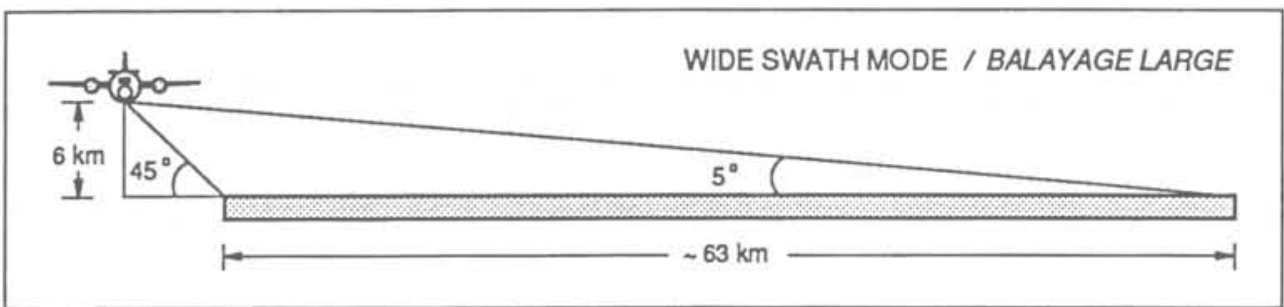




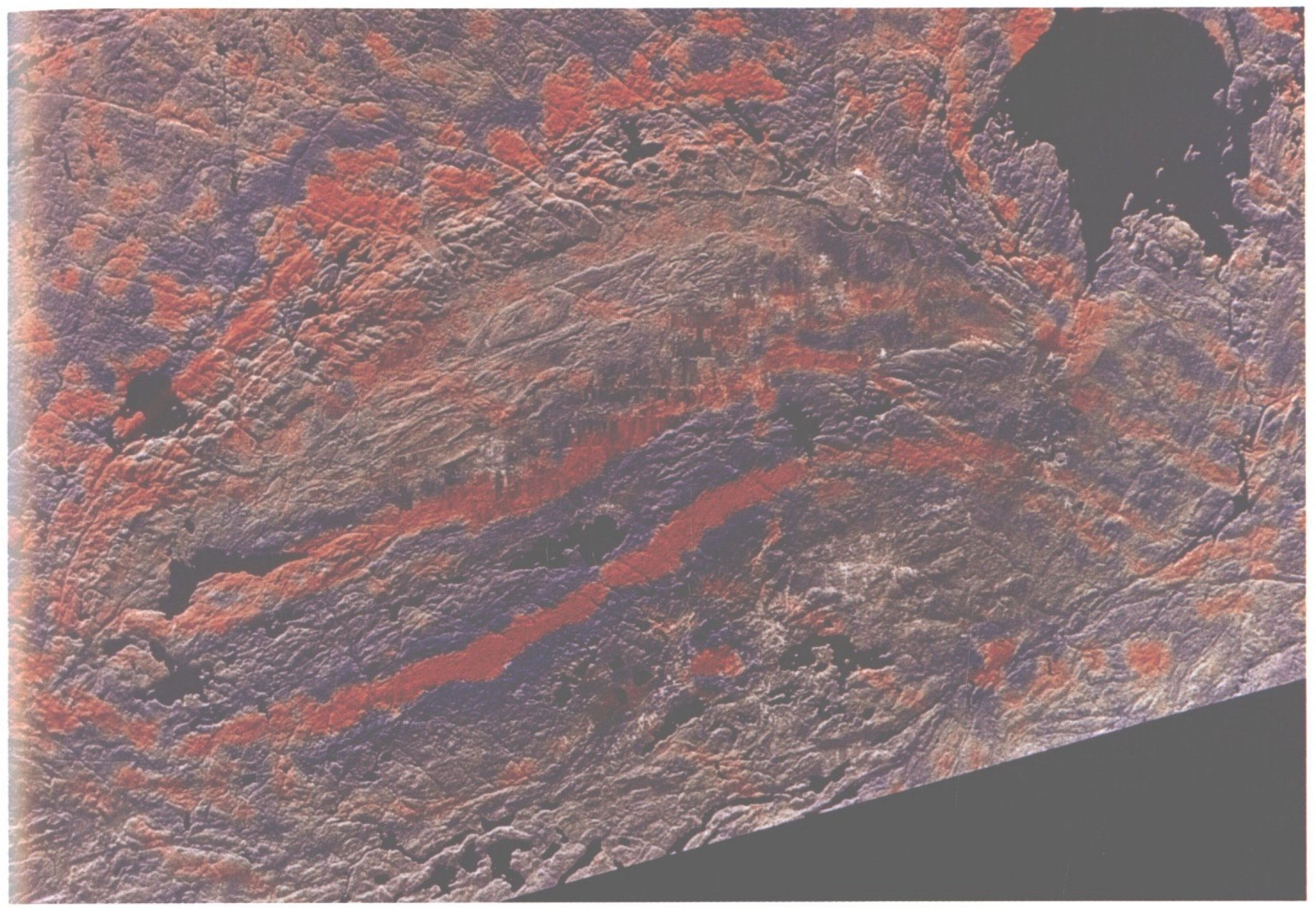

Figure 2.-An enhanced image of the Sudbury structure, Ontario, Canada. The image combines magnetic vertical gradient, C-band SAR, and TM band 4 by using an IHS color display transform. As a result, faults, dikes, and the Sudbury ring structure are clearly visible from this enhancement. Taken from Rheault and others (1991).

Sudbury basin, and figure 2 shows the same area enhanced by a combination of the SAR image, magnetic data, and a TM image. The enhancement included filtering, contrast stretching, and color transformation performed on each data set. To reduce the speckle in the SAR images, a $3 \times 3$ medium filter was used. A $9 \times 9$ high-pass filter and a $25 \times 25$ low-pass filter were convolved over the medium filter. This enhances the fracture systems. IHS color transformation was applied to the three stretched images (high-pass SAR, Landsat TM band 4 , and magnetic vertical gradient) in order to produce the enhanced image shown in figure 2 (Rheault and others, 1991). Harris (1991) also found the combined IHS transform SAR and magnetic images to be a useful product for structural and lithologic mapping in support of gold-exploration programs in Nova Scotia.

Other techniques combining Seasat SAR and geophysical data have been used for structural interpretation in support of hydrocarbon exploration in the western sedimentary basin of Canada. A combination of SAR, TM, and magnetic vertical gradient data created an enhanced structural image that was used to produce lineament density maps (Misra and others, 1991).

\section{Geologic hazards}

$\mathrm{D}_{\text {ata integration techniques and the visual interpretation of SAR }}$ data are as important to geologic hazards studies as they are to geological mapping and exploration programs. McFall and Singhroy (1989) have combined SAR and TM images to create image maps that were used to delineate local fracture systems and "pop ups" for seismic hazard studies in southern Ontario. In other areas, Roy (1991) has used SAR mosaicked images to interpret geologic structures and types of motion associated with the Charlevoix seismic zone in Quebec. Also, Li and others (1989) have combined SAR and SPOT data to study regional tectonic activity that was associated with the Nahanni earthquakes of 1985 and 1988 in the Northwest Territories. 
Table 1. - Summary of results of radar geology studies in Canada [See text for explanation of acronyms]

\begin{tabular}{ll}
\hline Category and study (reference) & Objective \\
\hline Geological mapping & \\
Wawa, Ontario & To integrate remote sensing and \\
(Mussakowski and others, & geoscience data in support of \\
$1991)$. & multidisciplinary geological \\
& mapping program.
\end{tabular}

Sudbury, Ontario

(Lowman, 1991).

Sudbury, Ontario

(Bowie and others, 1992).

Cape Breton Island,

Nova Scotia

(Prince and Akhavi, 1990).

Bathhurst Inlet,

Northwest Territories

(He and Wang, 1990).

Sudbury and southern Ontario (Singhroy and others, 1992).

Port Stanley, Ontario

(Kenny and others, 1991).

Nelson front, Manitoba (Rao and others, 1989).

Central Newfoundland (Graham and Grant, 1990).

\section{Mineral exploration}

Sudbury Basin, Ontario

(Rheault and others, 1991).

Techniques and results

A coregistered digital geoscience and remote sensing data base was created.

Customized set of enhanced multiple data products was used for visual interpretation (for example, composite of SAR, magnetic data, and geology)

Integration process involved selective uses of bedrock and surficial geology, aeromagnetic data, Landsat TM, and airbome SAR.

Relationships were established among vegetation, surficial material, lithology, and structure.

To evaluate simulated orbital SAR for geological mapping.

To interpret shape of Sudbury structure.

To integrate digitally DTM, geological map of Sudbury region, SAR wide swath, and geology derived from SAR.

To correlate and integrate airborne SAR, Landsat TM, DTM, geological, and geophysical data sets.

To use textural analysis for automatic identification of lithologic units from airborne SAR images.

To use airborne SAR images for Quaternary mapping of several different glaciated terrains in Ontario and Manitoba.

To update Quaternary mapping from airborne SAR and multispectral data.

To develop integrated remote sensing technique for mapping low-relief structures across the Nelson front.

To show the applicability of SAR as a geological reconnaissance tool.

To develop techniques for combining SAR and geophysical data in support of mineral exploration in the nickel-copper Sudbury mining district.
Visual interpretation of wide-swath image $(60 \mathrm{~km})$ to determine size and ellipticity of Sudbury structure

Narrow-swath image $(18 \mathrm{~km})$ was useful in mapping detailed structures and unmapped basaltic dikes.

Image map of 1:250,000-scale lithology and wide-swath SAR was produced as a standard product for regional geological mapping.

IHS transform was used for data integration.

Two look directions were necessary to map multidirection lineaments, which facilitated structural interpretation of sedimentary basin in southwestern Cape Breton Island.

SAR and DTM show poor correlation with lithology and geophysical units.

Textural measures of SAR data produced enhanced images that assisted in lithologic discrimination and in planning of geological mapping survey.

In flat areas, variability in soil moisture interpreted from springtime SAR corresponds to different textures (grain size) of glacial sediments and thereby aided in surficial mapping.

A $5 \times 5$ filter and stretched springtime SAR combined with TM bands 3 and 5 produced an image that enabled the delineation of glacial materials and landforms.

In Boreal forest areas (for example, northern Manitoba), a TM and SAR composite image provided both textural and spectral data that facilitated the mapping of engineering-terrain units.

Images produced from springtime airborne SAR ( $\mathrm{C}-\mathrm{HH}$ and $\mathrm{X}-\mathrm{HH})$ and multispectral data are more suited for interpretation of .landforms and surficial materials than are existing black and white 1:15,840-scale aerial photographs. The composites produced are the result of principal components 1 and 3 (blue and red) of the airborne SAR and multispectral data and a stretched band 7 of the multispectral image.

C-band SAR combined with TM was interpreted to provide information on deformational patterns in low-relief Precambrian terrains. The glacial overburden cover was reduced by using a simple geographic information system and Bayesian statistical integration.

Visual interpretation of wide-swath C-band SAR. The large depression angle in the far range enhanced small relief features and surface textures. Major new lineaments, fold pattern, and foliation were mapped. Morainal topography, hummocky and ribbed moraines, coarsely textured tills, and surface erratics were identified easily.

An image was produced from airborne SAR $(\mathrm{C}-\mathrm{HH})$ and magnetic vertical gradient by the use of color and texture IHS transform to map dikes and faults.

An image was produced from a $9 \times 9$ high-pass SAR and was combined with TM band 4 in a color and texture transform to map faults. 
able 1.-Summary of results of radar geology studies in Canada-Continued

iee text for explanation of acronyms]

\begin{tabular}{|c|c|c|}
\hline Category and study (reference) & Objective & Techniques and results \\
\hline \multicolumn{3}{|c|}{ Mineral exploration-Continued } \\
\hline $\begin{array}{l}\text { Eastern Nova Scotia } \\
\text { (Harris, 1991). }\end{array}$ & $\begin{array}{l}\text { To produce a map of geologic } \\
\text { structure based on photogeologic } \\
\text { and computer-assisted analysis } \\
\text { of remotely sensed data and a }\end{array}$ & $\begin{array}{l}\text { Enhanced SAR and magnetic data were useful in mapping regional structure. } \\
\text { IHS transform radar and geophysical images provided a useful visual product for struc- } \\
\text { tural and lithological mapping. }\end{array}$ \\
\hline
\end{tabular}

limited field program.

To evaluate the interpreted structural map with respect to regional tectonic framework and known gold occurrences.

\section{Hydrocarbon exploration}

Peace River district, Alberta, Canada

(Rheault and others, 1991).

Western sedimentary basin, Canada (Misra and others, 1991).
To develop techniques for combining SAR and geophysical data in support of hydrocarbon exploration in the Peace River district.

To use SAR and TM data to map lineaments for the entire sedimentary basin.

To integrate satellite Ineaments and magnetic, geological, and oil and gas well data to search for additional hydrocarbon traps.

\section{Geologic hazards}

Prince Edward County, Ontario To use airborne SAR, TM, and (McFall and Singhroy, 1989).

Seismic hazard in Charlevoix impact structure, Quebec (Roy, 1991).

Nahanni earthquakes, Northwest Territories (Li and others, 1989). springtime infrared photographs for mapping neotectonic features and their drift cover in flat terrain.

To map from airborne SAR intersecting faults in the Charlevoix seismic zone.

To use C-band SAR and SPOT for studying regional tectonic activity associated with Nahanni earthquakes of 1985 and 1988.
Color composite image of combined SAR and TM bands 3, 5, and 4 (BGR, blue, green, red) was produced to map tonal anomalies and faults.

Seasat SAR and TM images reflect basement faulting beneath $1,000 \mathrm{~m}$ of glacial and Paleozoic sediments.

The faults influence the sedimentation patterns, differential compaction of sediments, location of carbonate reefs, and dolomitization processes.

Lineament density maps show good correlation with oil and gas fields and were used to search for new traps. Northeast and northwest sets of lineaments transect the entire western sedimentary basin.

TM bands 4, 5, and 7 composite and springtime SAR image provided enhancement for locating local fracture systems and large "pop ups." However, because of very flat terrain, large-scale infrared photographs were more useful for mapping fracture systems and small "pop ups."

SAR digital mosaicked images were interpreted to produce a structural model of the Charlevoix seismic zone. North-south lineaments further north along the Saguenay River, lineaments parallel to the Saguenay graben and St. Lawrence River, and fine intersecting lineaments in the area were significant in terms of types of motion.

Integrated C-band SAR, SPOT, and earthquake epicenter data were used to map fracture systems associated with the Nahanni earthquakes. Low scan angle of wide swath $(60 \mathrm{~km})$. C-band SAR enhanced lineaments and different sun angle of SPOT complemented shadow areas of SAR data.

\section{Conclusion}

The summary of techniques and results in table 1 and the above descriptions demonstrate the potential of SAR in multidisciplinary geological investigations. Although these early results are encouraging, more techniques need to be developed for different areas, particularly in arid and tropical terrains. It is evident, however, that SAR data will be a valuable source of information in the study of global geoscience processes.

\section{References}

Bowie, C., Huppe P., and Glynn, J.E., in press, Experiment in combining geology maps with terrain relief data, in GIS 92, Surveys, Mapping and Remote Sensing Sector, Ottawa, Ontario, Canada, 1992: Canada Department of Energy, Mines and Resources.

Graham, D.F., and Grant, D.R., 1990, A test of airborne side-looking Synthetic Aperture Radar in central Newfoundland for geological reconnaissance: Canadian Journal of Earth Sciences, v. 28, p. 257-265.

Harris, J.R., 1991, Mapping of regional structure of eastern Nova Scotia using remotely sensed imagery: Implications for regional tectonics and 
gold exploration: Canadian Journal of Remote Sensing, v, 17, no. 2, p. 122-136.

He, Doug-Chen, and Wang, Li, 1990, Recognition of lithologic units in airborne SAR images using new texture features: International Journal of Remote Sensing, v. 11, no. 12, p. 2337-2344.

Kenny, F.M., Singhroy, V.H., and Barnett, P., 1991, Application of airborne multispectral and SAR images for Quaternary mapping, in Thematic Conference on Geologic Remote Sensing, 8th. Denver, Colorado, USA, 1991, Proceedings: Ann Arbor, Michigan, USA, Environmental Research Institute of Michigan, p. 1449-1461.

Li, B., Moon, W.M.. Won, J.S., Lamontagne, M., Slaney, V.R., and Graham, D., 1989, Application of satellite remote sensing technique in the geological investigation of Nahanni earthquake area, in Thematic Conference on Remote Sensing for Exploration Geology, 7th, Calgary, Alberta, Canada, 1989, Proceedings: Ann Arbor, Michigan, USA, Environmental Research Institute of Michigan, p. 615-626.

Lowman, P.D., 1991, Original shape of the Sudbury structure, Canada: A study with airborne imaging radar: Canadian Journal of Remote Sensing, v. 17 , no. 2, p. $152-161$.

McFall, G., and Singhroy, V.H., 1989, Remote sensing applications to neotectonics studies in southern Ontario, in Thematic Conference on Remote Sensing for Exploration Geology, 7th, Calgary, Alberta, Canada, 1989. Proceedings: Ann Arbor, Michigan, USA. Environmental Research Institute of Michigan, p. 533-546.

Misra, K.S., Slaney, V.R., Graham, D., and Harris, J., 1991, Mapping of basement and other tectonic features using Seasat and Thematic Mapper in hydrocarbon-producing areas of the western sedimentary basin of Canada: Canadian Journal of Remote Sensing, v. 17, no. 2, p. 137-151.

Mussakowski R., Trowell, N.F., and Heather, K.B., 1991, Digital integration of remote sensing and geoscience data for the Goudreau-Lochalsh area, Wawa, Ontario: Canadian Journal of Remote Sensing, v. 17, no. 2 , p. 162-173.

Prince, J.D., and Akhavi, M.S., 1990, Integration of C-band imagery with TM, geophysical and geological data, Cape Breton Island: Program summaries: Nova Scotia Department of Mines and Energy Report no. $90-3$, p. 44.
Rao, G.S.K., Won, J.S., Moon, W.M., Slaney, V.R., Graham, D.F., and Lowman, P.D., 1989, Integrated imaging experiment with C-SAR and other geological image data across the Nelson front, northern Manitoba, in Thematic Conference on Remote Sensing for Exploration Geology, 7th, Calgary, Alberta, Canada, 1989, Proceedings: Ann Arbor, Michigan, USA, Environmental Research Institute of Michigan. p. 579-590.

Rheault, M., Simard, R., Garneau, C., and Slaney, V.R.. 1991, SAR Landsat TM-geophysical data integration utility of value-added products in geological exploration: Canadian Journal of Remote Sensing, v. 17. no. 2, p. 185-190.

Roy. D., 1991, Intersecting faults at the NE tip of Jacques Cartier horst, in Multi-Agency Group for Neotectonics in Eastern Canada Annual Meeting, Ottawa, Ontario, Canada, 1991, Summary of MAGNEC annual meeting: Atomic Energy Control Board, AECB Open-File 34-5-4-0, p. $18-20$.

Singhroy, V.H., Kenny, F.M., and Barnett, P.J., 1992, Radar imagery for Quaternary geological mapping in glaciated terrains: Canadian Journal of Remote Sensing, v. 18 , no. 2, p. $117-123$.

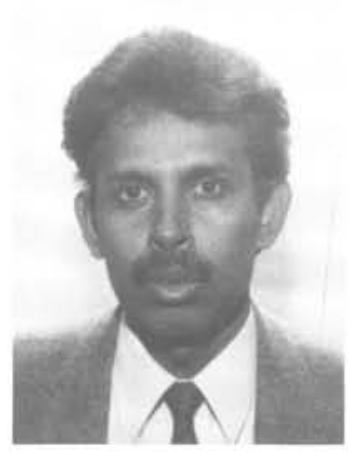

Dr. V.H. Singhroy is Chairman of the Advisory Board on Remote Sensing of the International Union of Geological Sciences, Research Scientist in geological remote sensing, and Scientific Advisor at the Canada Centre for Remote Sensing in Ottawa, Ontario, Canada. 